
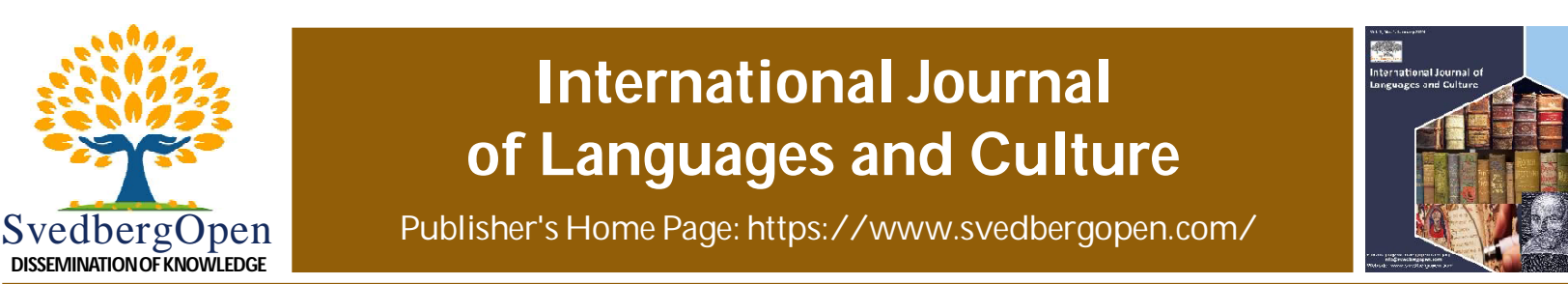

Research Paper

\title{
Comparative cognitive study of Uncle Tom's Cabin by Harriet Beecher Stowe and The Underground Railroad by Colson Whitehead
}

\author{
Afsaneh Askar Motlagh ${ }^{1 *}$, and Sahar Jamshidian ${ }^{2}$ \\ ${ }^{1}$ English language researcher and teacher University of Malayer, Malayer university, Hamadan Province, Malayer, Iran. \\ E-mail: afmotlagh@yahoo.com \\ ${ }^{2}$ Assistant Professor of English, Malayer university, Hamadan Province, Malayer, Iran. Email: Sahar 84 ir@yahoo.com
}

\section{Article Info}

Volume 1, Issue 2, June 2021

Received : 09 December 2020

Accepted : 07 May 2021

Published : 05 June 2021

doi: 10.51483/IJLC.1.2.2021.19-22

\begin{abstract}
Over the past three decades cognitive approaches to literature has been in the center of attention. These approaches include the development of methodologies for describing both the production and reception of literary texts. Metaphor has been important for understanding the workings of the mind throughout the cognitive disciplines. George Lakoff and Mark Johnson in their book, Metaphors We Live By (1980), define conceptual metaphors as our means of understanding abstract concepts in terms of more concrete ones. Many authors deploy literary devices like metaphor and irony to convey their meanings. The current study will analyze that metaphor is used to describe the indescribable phenomena such as, slavery, racism and especially double oppression on black women in Harriet Beecher Stowe's Uncle Tom's Cabin (1852) and Colson whitehead's The Underground Railroad (2016). By using metaphorical language, these authors provide a critique of the white domination to change the consciousness of the oppressed women and to manifest what they are in contrast to what they should be. The result indicates that Whitehead has given life to the same slavery story of Uncle Tom's Cabin which faded into obscurity over centuries to emotionally engage a global audience at the present time to remind that all these oppressions exist even today.
\end{abstract}

Key Words: Cognitive Linguistics, Metaphor, Slavery, Freedom, Black feminism.

(C) 2021 Afsaneh Askar Motlagh, and Sahar Jamshidian. This is an open access article unde the CC BY license (https://creativecommons.org/licenses/by/4.0/), which permits unrestricted use,

distribution, and reproduction in any medium, provided you give appropriate credit to the original author(s) and the source, provide a link to the Creative Commons license, and indicate if changes were made.

\section{Introduction}

A literary work brings new cognition for us as a reader that is, fiction causes us to "attend to the world and what is in it, in a way that will involve the exercise of all our faculties" (Diamond, 1995). It gives us new ways and means of seeing the world, it also reorients our knowledge, and enriches our perception and understanding of the world. In general, it deepens our knowledge by bringing noteworthy details of the world to the minds and hearts. Great cognitive value can be conferred to the work of literature because of different functions it has, like pleasure giving function, educational function or the function of exploring political or social circumstances in order to incite people's reactions or to bring change in their attitudes.

Literature offers many kinds of experiences that people could not have in their actual lives, like the experience of distant historical eras or the experience of having perceptions, memories, beliefs, or desires different from their own. If an

* Corresponding author: Afsaneh Askar Motlagh, Malayer university, Hamadan Province, Malayer, Iran. E-mail: afmotlagh@yahoo.com

2788-404X/C 2021. Afsaneh Askar Motlagh and Sahar Jamshidian. This is an open access article distributed under the Creative Commons Attribution License,which permits unrestricted use, distribution, and reproduction in any medium, provided the original work is properly cited. 
audience imagines and learns what it is like to be another person, then he or she might try to make policy or ethical decisions on that basis. Learning how an experience feels like, such as, what it is like to feel hunger, pain, or torturerequires metaphor because it involves reader's imaginative engagement with the story in the cognitive process. The central element in cognitive studies is metaphor.

\section{Methods}

Aristotle is the first person who praised and encouraged the use of metaphor and simile for decoration and utility, in particular, metaphor's ability to create wonder and pleasure. According to Aristotle, a metaphor involves the transference of a word from one semantic field to another that is totally unrelated. Unlike Aristotle, modern theorists, George Lakoff and Mark Johnson, maintain that a metaphor is based on concepts, not single words. They say, "metaphor is typically viewed as characteristic of language alone, a matter of words....on the contrary,... metaphor is pervasive in everyday life, not just in language but in thought and action" (Lakoff and Johnson, 1980). Metaphor is "a natural phenomenon" (Lakoff and Johnson 1980) which takes place beyond language as it is found primarily in thought and action. So, according to them, the way we think and act is metaphorical, "the locus of metaphor is not in language but in the way we conceptualise one mental domain in terms of another" (Lakoff, 1993). Language users understand something new by metaphorically projecting their old experiences to their new experiences, that is, via "correspondences in our experiences" (Lakoff, 1993), so a target domain is conceptualized by using a source domain which is familiar to us.

Lakoff and Mark Turner bring a primary explanation of the LIFE IS A JOURNEY metaphor which is of specific note here, and illustrate the way metaphor as a linguistic and psychological process, works as a significant cognitive mechanism behind our cultural and linguistic issues. They have examined the effects of travel- and motion-based mappings in their study of metaphor theory. Lakoff and Turner consider the themes of passage of time, life, birth, and death which are connected to travel imagery, in their works. According to them, "the LIFE IS A JOURNEY metaphor is one of the most powerful tools we have for making sense of our lives and for making decisions about what to do and even what to believe" (65). Travel-related metaphors are central in metaphor theory. These metaphors are grounded in our cultural beliefs that "people are supposed to have purposes in life, and they are supposed to act so as to achieve those purposes" (Lakoff and Turner, 1989). This creates a structure of a journey: "it has a starting point, endpoint, path, places we want to reach along the way, and, commonly, companions, difficulties, provisions, and so on" (Lakoff and Turner, 1989).

\section{Discussion}

Stowe put special emphasis on the horrors suffered by maternal victims of the system. The cruelty severed ties between black mothers and children recur throughout history. The mothers and motherless children in Uncle Tom's Cabin show the human cost of the system. As regards the novel's plot, to settle his debts, Mr. Shelby, a slave owner, had to sell his faithful slave, Tom, and Harry Harris, son of the slave Eliza Harris. Since Uncle Tom was an old loyal and spiritual man, he did not want to disobey his master even at the expense of losing his wife and children for ever. Eliza who could not stand losing her child, planned to flee to Canada to join her husband, George, who had already fled to Canada. Later, Tom was auctioned off and brutal Simon Legree bought him. In Legree's plantation, Cassy and Emmeline, Legree's mistress, planned to kill Legree and escape. Freedom is conceptualized in terms of the domain of physical motion in Freedom Is a Journey Metaphor. There are metaphorical correspondences in this trope: The escapees are travelers in a journey, with a goal as destination to be reached. This metaphorical journey has stages that must be visited or traveled through. The point of embarkation for reaching freedom here is Cabin, a place that the main protagonists of the story, Eliza, Cassy, Emmeline even George, went to consult with Tom about their plan of escape and got prepared for that long dangerous travel.

This journey consists of moving in a specific way toward a destination, of having the necessities of removing impediments, of finding assistance or guidance, and of passing through different places before reaching. Tom here acted as a guidance and assistance toward liberation. Tom's self-sacrifice and love did not let him to disclose the whereabouts of the runaway slaves to Legree so he slashed Tom so severely to his death. He was a devotee acted as a member of the Underground railroad and in fact, he turned his home into a stop on the underground railroad path.

The experiences on the way as difficulties are conceptualized as BURDENS. We can take into consideration the submappings, "DIFFICULTIES ARE BURDENS" and "DIFFICULTIES ARE IMPEDEMENTS TO MOTION." A difficulty is something that can emerge and impede motion to a goal as destination. The impediments such as hills, rough patches, swamps, rivers on the way that make travelers being hindered on their journey. These are what protagonists of the story Eliza, Cassy, and Emmeline faced during their running toward the North. 
Whitehead made use of figurative device to represent such an incomprehensible atrocity towards women of color. We can see here the same theory is applicable to The Underground Railroad. Cora, an enslaved woman, along with a male fellow slave named Caesar flee from a Georgia plantation and journey toward free North on an underground train. Similarly, as we see, Whitehead describes the target domain of freedom in terms of easily understandable source domain of railroad. Freedom is conceptualized as a train journey. Again we can have here the mapping of "PROGRESS TOWARD AGOAL IS MOVEMENT ALONGA PATHTOWARDADESTINATION”, “SUSPENSIONOFACTION IS THE STOPPING OF MOVEMENT" and "FREEDOM OF ACTION IS THE LACK OF IMPEDIMENT TO MOVEMENT" (Lakoff and Johnson, 1980). "DIFFICULTIES ARE COUNTERFORCES, DIFFICULTIES ARE LACKS OF ENERGY” (cf. Lakoff and Johnson, 1999), DIFFICULTIES ARE DARKNESS, and DIFFICULTIES ARE FREEZING WEATHER are all experienced in fugitive-slave story of such heroes as Cora and Caesar.

Due to extreme and unique nature of slavery, it is difficult to write about the horrific events like lynching, rape, sterilization, etc., "the ones so imaginative in their monstrousness that the mind refused to accommodate them" (Domestico, 2016). The black experience of perpetual unfreedom and exploitation shared by characters of both novels Eliza, Cassy, Emmeline, and Cora. The stations on the way "North Carolina-South Carolina-Indiana" that Cora gets off the underground train and stays temporarily, along with the plantation, are full of nightmarish experiences of slavery. Metaphors tend to create a visual image in our minds, which is important for waking people of the present time to the real truth. It is used out of necessity rather than pure ornamentation. Utilizing the mechanisms of the slavery, as metaphorical means, brings a critique by focusing our attention on the violation of rights, the commodification of human beings, raping them, sterilizing them, turning them to a guinea pig and exploitation of both natural and human resources, as Cora witnessed traveling further north, makes a comparison between the slavery and contemporary realities possible and necessary.

To understand how the conceptualization of the above-mentioned slavery metaphors could have been, we have to reimagine what kind of life stories, bodily experiences, and cultural settings constituted slaves' worlds. The intensive dehumanization which is highlighted in the different scenes of both stories turns blacks into property and animal. Patricia Collins believes that "Western racism make a logical circuit which assumes that Black people are like animals...It returns frequently to the metaphor of women as slaves as the core trope for women's oppression" (Collins, 2017a). The conceptual metaphors such as WOMEN ARE ANIMALS and WOMEM ARE GOODS, based on the metaphorical system of "The Great Chain of Being," put women and slaves below humans. It means many things like human behaviors, attributes, rights, and also values are taken away from women and colored people.

As Collins asserts, "Whether racism or sexism, resistance is always present. Resistance is embedded within domination" (2017b). Freedom and the strict quest for freedom, was the mainstay of women's identities. In the novel, the journey is the essence of the story and "geography is plot: the South represents iniquity and bondage, the North enlightenment and freedom" (Schulz, 2016).The threat of these bodily violations sets the protagonists on a path of almost constant motion toward North so the orientational metaphor of FREEDOM IS UP is considered.

In Stowe's work, the END POINT of this metaphorical journey is an actual place on a free land where these female escapes reach at the end of story. The last chapter of Whitehead's work is titled "The North". Cora injured Ridgeway, her slave catcher pursuing her throughout the story, fatally and now free, she went with a black man on his wagon to the unknown, but the story does not show that Cora reached the free North. The reader never knows, whether Cora reaches freedom or not because the "wagon was headed west" (Whitehead, 2016). The North stands as a symbol for freedom in slave narratives, but Cora was sent to the west.

The collection of metaphors discussed here is thus a reminder of the crucial importance of not only the literary study of slavery but also the incorporation of metaphor into the way the past is being recalled in its unfortunate perpetual presence. Whitehead chooses the abolitionist historiographical notion of the underground train network to draw parallels between recent tensions in the United States concerning police brutality and "the Black Lives Matter movement" and the race connections in the antebellum period. Numbers of innocent blacks who were killed by the cops arousing nationwide protests. White people continue to use race as an indication of difference, and hence inequalities, so black people, as a capitalist source of cheap labor, are imprisoned more than white people to be exploited in the growing prison-industrial complexes. Collins contends that it is a "belief in upholding color blindness which masks the continued inequalities of contemporary racism" (Collins, 2006).

\section{Conclusion}

This study examines the female protagonists' persona, the trauma of their lived experiences, their resistance and survival. To achieve this purpose, Stowe and Whitehead tracked the formation of the black women's identity through the slavery 
system and the role slave-trading has played in degrading their identity. Metaphor creates or communicates knowledge, the mental representations and knowledge of abstract concepts that we cannot physically experience. In this way, readers can metaphorically conceptualize vague, abstract domains of knowledge, like life, suffering, or freedom. The concept of freedom has been explored by virtue of the conceptual metaphor LIFE IS A JOURNEY. Stowe and Whitehead described the target domain of Freedom in terms of the more concrete source domain of journey. Whitehead has chosen the old story of racism to depict the idea that racism exists today and must be corrected. By focusing on atrocities inflicted on slaves in the past, Whitehead gives readers a way to understanding how these atrocities might continue to oppress black people today. These novels develop a new consciousness and knowledge in black women to resist the exploitations by standing up against the strategies, ideologies, and stereotypes applied to them in order to bring about progressive social changes.

\section{Conflicts of interest}

The authors declared that there are no conflicts of interest.

\section{References}

Collins, Patricia, Hill. (2006). From black power to hip hop: Racism, nationalism, and feminism. Philadelphia, PA: Temple University Press.

Collins, Patricia, Hill. (2017a). Simone de Beauvoir, Women's Oppression and Existential Freedom. Hengehold, Laura., and Nancy, Bauer, (Eds.), A Companion to Simone de Beauvoir, John Wiley \& Sons Ltd. 325-339.

Collins, Patricia, Hill. (2017b). The difference that power makes: Intersectionality and participatory democracy. Investigaciones feministas, 8(1), 19-39.

Diamond, Cora. (1995). Anything but Argument? Her The Realistic Spirit: Wittgenstein, Philosophy, and the Mind, 291-308, Cambridge, The MIT Press.

Domestico, Anthony. (2016). Rails and ties: Colson Whitehead's important new novel blends the savage realism of slavery and a magical, actual underground railroad, with community the light at the end of the tunnel.On line: https://epaper.bostonglobe.com/BostonGlobe/article_popover.aspx?guid=32b338b5-oa74-4052-bd5.

Lakoff, George. (1993). The contemporary theory of metaphor. In Ortony. (Ed.), Metaphor and Thought. 202-205.

Lakoff, George., and Johnson, Mark. (1980). Metaphors We Live By. The University of Chicago Press.

Lakoff, George., and Turner, M. (1989). More Than Cool Reason. The University of Chicago Press.

Lakoff, George., and Johnson, Mark. (1999). Philosophy in the Flesh: the Embodied Mind and Its Challenge to Western Thought. New York: Basic Books.

Schulz, Kathryn. (2016). The Perilous Lure of the Underground Railroad. Hardly anyone used it, but it provides us with moral comfort — and white heroes. On line: https://www.google.com/amp/s/www.newyorker.com/magazine/2016/ 08/22/the-perilous-lure-of-the-underground-railroad/amp.

Whitehead, Colson. (2016). The Underground Rail Road. Doubleday, Penguin Random House.

Citethis article as: A fsaneh A skar M otlagh and Sahar Jamshidian (2021). Comparative cognitivestudy of Uncle Tom's Cabin by Harriet Beecher Stowe and The U nderground Railroad by Colson Whitehead. International J ournal of Languages and Culture. 1(2), 19-22. doi.org/ 10.51483/ IJLC.1.2.2021.19-22 